\title{
WHAT MIGHT A SUSTAINABLE POPULATION OF TREES IN WOOD-PASTURE SITES LOOK LIKE?
}

\author{
Keith J. KIRBY ${ }^{1}$
}

\begin{abstract}
Wood-pastures are important for their open-ground biodiversity and for the old trees they contain. However, younger trees to replace the current generation of old trees are often scarce, a potential threat to the future of the habitat mosaic and of species dependent on the trees. A simple model was used to illustrate how many younger trees might be expected under different assumptions of desired final density of old trees and rates of loss as trees age for an oak-dominated wood-pasture. From these the overall canopy cover of the landscape was estimated under an active pollarding regime and where the trees grow to full crown size. Canopy cover was often five times as great under full crown as under a pollarding regime; much of the canopy cover was in the younger (often missing) cohorts. The openness of current wood-pastures is in part a consequence of the absence of a sustainable tree population structure. Some protected sites may be too small to allow space for the missing generation of trees and at the same time retain current levels of openness. Analogies between current wood-pasture structures and 'natural wood-pastures' of the pre-Neolithic era must take account of the missing generations of trees. Keywords: model, natural forest landscape, oak, old tree, pollard.

Izvleček

Pašniki z drevesi so pomembni za biodiverziteto zaradi njihove odprtosti in zaradi prisotnih starih dreves. Vendar so mlada drevesa, ki naj bi nadomestila trenutno generacijo starih dreves redka, kar predstavlja potencialno grožnjo mozaičnemu habitatu in vrstam, ki so odvisne od prisotnosti dreves. Uporabili smo preprost model, ki predstavlja koliko mladih dreves lahko pričakujemo v različnih predvidevanih gostotah starih dreves in različnih stopnjah odmiranja starih dreves zaradi starosti na pašniku, kjer dominirajo hrasti. Iz tega smo ocenili skupno pokrovnost krošenj v krajini, če se drevesa aktivno obrezuje ali le-ta zrastejo do polne velikosti krošnje. Pokrovnost krošenj je pogosto do petkrat večja, če drevesa zrastejo do polne velikosti, kot če jih obrezujemo. Večina pokrovnosti krošenj je zaradi mlajših dreves (ki pa pogosto manjkajo). Trenutna odprtost pašno-drevesnih podsistemov je delno posledica odsotnosti trajnostne strukture drevesne populacije. Določene zaščitene površine so verjetno premajhne, da bi se lahko manjkajoče generacije dreves obnovile in da bi se obenem ohranila trenutna stopnja odprtosti pašnika. Pri analogiji med sedanjimi pašno-drevesni podsistemi in naravnimi pašniki z drevesi iz obdobja pred Neolitikom moramo upoštevati manjkajoče generacije dreves. Ključne besede: model, naravna gozdna krajina, hrast, stara drevesa, obrezano na glavo.
\end{abstract}

\section{INTRODUCTION}

Wood-pastures consist of varying amounts of tree and woodland cover, with extensive open areas, grazed by livestock (particularly cattle) or deer (Rotherham 2013, Hartel \& Pleininger 2014). They are widely valued for the richness of their plant and animal communities (e.g. Newton 2010, Bergmeier \& Roellig 2014, Dengler et al. 2014,
Garbarino \& Bergmeier 2014, Hartel et al. 2014). Vera (2000) has proposed that wood-pasture systems may be closer in their structure and composition to the natural/pre-Neolithic landscape than closed high-forest, although this is not generally agreed (e.g. Hodder et al. 2009). However, irrespective of whether they are analogues of the past natural landscape or not, they are increasingly recognised as important cultural land-

\footnotetext{
${ }^{1}$ Department of Plant Sciences, South Parks Road, Oxford, OX1 3RB, UK, keith.kirby@bnc.oxon.org
} 
scapes (e.g. Tubbs 1986, Rackham 1989, Harding \& Wall 2000, Bieling \& Konold 2014, Kizos 2014).

In Britain wood-pastures are particularly the areas where concentrations of old trees occur. These are important in their own right for biological and cultural reasons (Read 2000); in addition they support rich populations of epiphytic lichens and saproxylic invertebrates (e.g. Harding \& Rose 1986, Rose 1993, Falk 2014). During the 1990s various initiatives raised the profile of wood-pastures and old trees in conservation practice in Britain (Kirby et al. 1995). The UK Biodiversity Action Plan identified wood-pastures as a priority type requiring the production of a Habitat Action Plan (English Nature 1998). Many of the most important wood-pasture sites were included in Special Areas of Conservation put forward under the European Union Habitats and Species Directive (Perry 2013, Kirby \& Perry 2014). In addition English Nature (the state conservation body in England) led a five-year programme of work - the Veteran Tree Initiative - which promoted the conservation of old trees generally (Read 2000); a citizen-science project to map old and interesting trees across the country was subsequently established (Butler 2014).

Wood-pastures are fragile ecosystems because they are intermediate between open-pastures and closed-canopy forests (Hartel \& Pleininger 2014). Maintenance of the biodiversity value of the open grassland/heath element of the system requires that the canopy cover remains relatively low, or key species may be shaded out. The old trees may also suffer from competition if the surrounding tree density becomes too great. However, too few young trees can also be a threat to the longterm survival of the species associated with the old trees (Stokland et al. 2012) and this was highlighted for British sites by for example Harding \& Alexander (1993). Management recommendations for wood-pasture sites often include the planting of new trees or protection of natural regeneration to help address the generation gap (Key \& Ball 1993).

In this paper I use a simple model to suggest what sort of tree population structure might allow a population of old trees to be maintained in perpetuity in a wood-pasture system and what this might mean in terms of the balance between tree-cover and openness on a site. The parameters for the model are based on those that might apply to a wood-pasture in lowland England, grazed by cattle or deer, where the main trees are oaks (Quercus robur L., Q. petraea (Mattuschka) Liebl.) with the oldest trees about 400-500 years old. However the approach could be applicable, with suitable changes to the parameters, to other types of system.

\section{METHODS}

The density of trees needed for the population of old trees to be sustainable depends on the target density of old trees $(n / h a)$, the number of younger age classes, and the rate of loss of trees in the transition from one age-class to the next: not every young tree that establishes will survive through several centuries to become an old tree. In the analysis I varied the target old tree density, the number of younger age classes present, and the rate of loss between age classes to give a range of different potential tree populations sizes. I added two variants for crown size: the first assumed that the trees were pollarded on a regular cycle; the second that they were open-grown maiden stems. The parameters used were based on field observations from a variety of studies to make them realistic: further details on each of these elements are given below.

These results were also compared to actual tree population data for two wood-pastures, one with a dense canopy cover, the other much more open.

\subsection{Target Density of Old trees (N/HA)}

The oldest generation of oaks in wood-pastures in Britain are commonly 400-500 years old (e.g. Watkins et al. 2003). Many saproxylic invertebrates and lichens associated with these old trees are considered to be poor colonists (e.g. Rose 1993, Hedin et al. 2008, ). Therefore the old trees which form their habitat should not be too far apart, to allow for easy movement between them. Mean densities of one, two, or four trees per hectare more than 400 years old were therefore used as the target, equivalent to a mean inter-tree distances of $100 \mathrm{~m}, 71 \mathrm{~m}$ and $50 \mathrm{~m}$ respectively.

\subsection{Periodic RATHER THAN ANNUAL REGENERATION CLASSES}

Small differences in tree age are unlikely to be significant as far as associated species are concerned, so it seems better to model regeneration 
as a series of episodic events, leading to populations consisting of cohorts or classes of different ages, similar to that described by Peterken \& Tubbs (1965) for the New Forest. Ranius et al. (2009) found that the probability of oaks (Quercus spp.) containing stem hollows was only $5 \%$ for trees less than 100 years old but c50\% for trees 200-300 years old. Two options were modelled: one in which the main episodes of regeneration occurred every 100 years and the second where the cohorts were more widely spaced at 150 years apart; any greater gap would be likely to mean that there was a break in continuity of features such as trees with large hollows.

\subsection{VARYING TREE SURVIVAL RATES IN THE TRANSITION FROM ONE AGE CLASS TO THE NEXT}

Trees die through bark-stripping by animals, disease, windblow, droughts leading to water shortage, competition from other trees, etc. (Stokland et al. 2012). The chances of a tree dying are small in any one year, but over the time (100 or 150 years) it takes for them to move through to the next cohort stage there is a strong chance that an extreme event such as a major drought or windstorm will occur which can kill a number of veteran trees in a very short period (e.g. Harding \& Alexander 1993). (Death here refers to the loss of the main trunk or pollard bole; there may be regrowth from the rootstock so that genetically the individual has not died, but from the point of view of the species associated with the old tree this is a new individual stem.)

There are relatively few estimates of the annual rates of tree death, but Bergman (2006) suggested a desirable population structure equivalent to loss of $0.5 \%$ trees per annum; Drobyshev et al. (2008) from a literature review suggested mean loss for Quercus spp. populations of around $1 \%$ per annum, with, for four populations of trees over 150 years old, a range of $0.2-3.5 \%$.

Two tree survival patterns were considered in the model based on the above figures. The simplest was that half the trees in any one cohort died before the transition to the next stage (representing an average annual loss of $0.7 \%$ per annum for a hundred-year cohort gap, or $0.48 \%$ per annum where the cohort gap was 150 years).

In field discussions around the management of wood-pastures it is often suggested that young trees may be more likely to die than older trees. Their trunks are less flexible than older individuals where much of the heartwood has rotted away; their centre of gravity may also be higher, particularly if full-crowned, increasing their vulnerability to wind-throw. Their smaller diameters also make them more vulnerable to being completely ring-barked by grazing animals because any given amount of bark removed represents a higher proportion of the total circumference on a small tree. In managed wood-pastures they may be more likely to be felled for their timber value, i.e. before they have started to develop internal hollows and rot.

Therefore the second survival pattern used assumed a lower death rate in the older age classes. The mean annual loss rate was as before for trees less than 300 yrs $(0.7 \%$ or $0.48 \%$ per annum depending on cohort gap), but with a reduced rate in the older classes whereby two out of three trees were assumed to survive the cohort transitions, equivalent to loss rates of $0.4 \%$ and $0.26 \%$ per annum respectively for 100 and 150 year cohort gaps.

\section{Target no of old trees ( $>400 \mathrm{yrs}$ ) per ha}

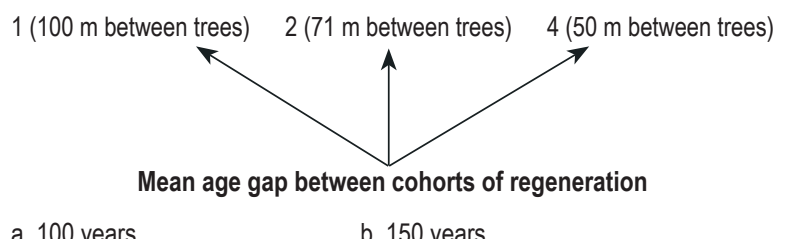

$\begin{array}{ll}\text { a. } 100 \text { years } & \text { b. } 150 \text { years }\end{array}$

Successor generations trees Successor generations trees present on site are therefore: present on site are therefore:

$>400$ yr old trees $301-400$ yr old trees 201-300 yr old trees $101-200$ yr old trees $50-100$ yr old trees

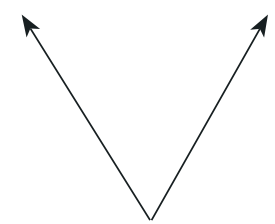

$>450$ yr old trees $300-450$ yr old trees $150-300$ yr old trees 50-150 yr old trees

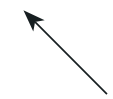

Crown size and management Options applied to each of the other combinations:

a. Trees regularly pollarded on a 10 yr cycle

b. Trees grown as maiden stems

Mean annual loss rates set at:

a. Equivalent to $0.7 \%$ of trees per annum for $100-y r$ age gap or $0.48 \%$ for 150 -yr age gap across all age classes

b. Equivalent to $0.7 \%$ of trees per annum for $100-y r$ age gap or $0.48 \%$ for 150 -yr age gap for age classes up to 300 years; and equivalent to $0.4 \%$ of trees per annum for 100 -yr age gap or $0.26 \%$ for 150 -yr age gap for age classes over 300 years

Figure 1: Outline of the different elements of the model. Slika 1: Pregled različnih elementov v modelu. 
Survival of trees beyond about 500 years was assumed to be too rare to be significant in terms of the overall population structure. Similarly no account was taken of trees less than 50 years old.

Population structures were then calculated by starting from the target final veteran tree density and calculating the numbers needed in successively younger cohorts according to the different assumptions (Figure 1). All calculations were performed using Excel spread sheets.

\subsection{TREE GOVER ACROSS THE LANDSGAPE}

The average crown size for trees of different ages and the number of trees in each age class per hectare were combined to give the total tree cover for different population structures.

The first set of crown cover calculations assumed that all trees were regularly pollarded on a ten-year cycle and that there were no differences between crown spread for trees of different ages in the same part of the pollarding cycle. Crown diameter was assumed to expand evenly up to a maximum of $10 \mathrm{~m}$, before it was cut again (Table 1). The mean crown size over the pollarding cycle $\left(22.4 \mathrm{~m}^{2} /\right.$ tree$)$ was then used in subsequent canopy cover calculations.

Table 1: Crown diameters assumed for trees worked on a 10 -yr pollarding cycle (next cut in year 10 ).

Tabela 1: Premeri krošenj predvideni na podlagi 10 letenega cikla obrezovanja (naslednji rez v letu 10).

\begin{tabular}{ccc}
\hline $\begin{array}{c}\text { Years since } \\
\text { pollarding }\end{array}$ & $\begin{array}{c}\text { Crown diameter } \\
(\mathrm{m})\end{array}$ & $\begin{array}{c}\text { Crown cover } \\
\left(\mathrm{m}^{2}\right)\end{array}$ \\
1 & 1 & 0.8 \\
2 & 2 & 3.1 \\
3 & 3 & 7.1 \\
4 & 4 & 12.6 \\
5 & 5 & 19.9 \\
6 & 6 & 28.3 \\
7 & 7 & 38.5 \\
8 & 8 & 50.3 \\
9 & 9 & 63.6 \\
10 & 0 & 0 \\
\hline
\end{tabular}

The second set of crown cover estimates was for situations where the trees had been allowed to grow as maiden stems or had long outgrown any pollarding cycle. Savill (1991) reports that crown diameter is closely correlated with stem diameter for oak, through the following relation- ship: Crown diameter $(\mathrm{m})=0.7728+0.1759$ stem diameter $(\mathrm{cm})$.

Observations of about 50 trees at Windsor Great Park suggest that this could be used for open grown trees up to about $120 \mathrm{~cm}$ diameter at breast height (dbh) (Figure 2). An age-crown diameter table (Table 2) was then constructed using this relationship; for trees greater than

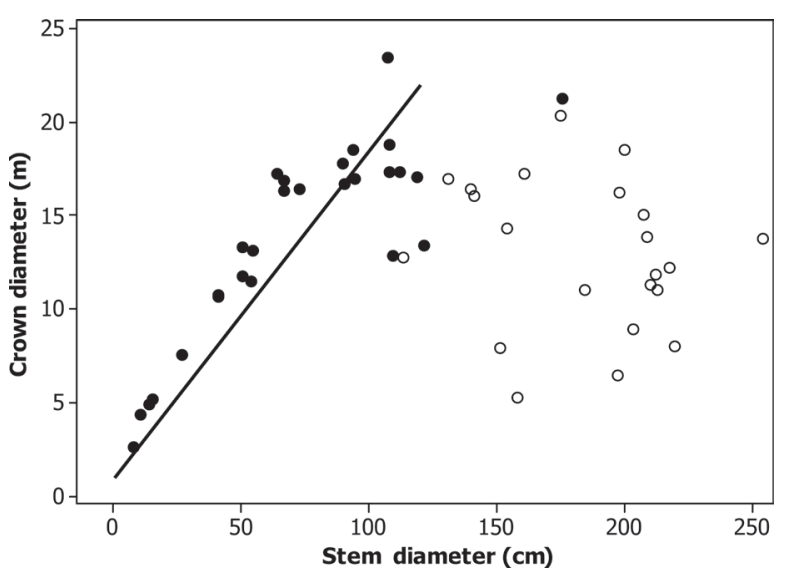

Figure 2: Crown diameter versus stem diameter for 50 free standing oak trees at Windsor Great Park (Berkshire): closed circles actively growing trees; open circles veteran trees. The line shows the expected relationship based on Savill (1991).

Slika 2: Premer krošenj v odvisnosti od premera stebla za 50 prostostoječih hrastovih dreves v parku Windsor Great Park (Berkshire): polni krožci- aktivno rastoča drevesa, prazni krožci - veterani. Črta predstavlja pričakovani odnos po Savill (1991).

Table 2: Mean crown diameters assumed for maiden oaks in different age classes.

Tabela 2: Povprečni premer krošnje hrastov v različnih starostnih razredih.

\begin{tabular}{cccc}
\hline Age class & $\begin{array}{c}\text { Mean } \\
\text { stem } \\
\text { diameter } \\
(\mathrm{cm})\end{array}$ & $\begin{array}{c}\text { Mean crown } \\
\text { diameter (m) derived } \\
\text { from Savill (1991) } \\
\text { and Windsor Great Park } \\
\text { observations }\end{array}$ & $\begin{array}{c}\text { Crown } \\
\text { cover } \\
\text { per tree } \\
\left(\mathrm{m}^{2}\right)\end{array}$ \\
\hline 100 yr cohort gap & & & \\
$50-100$ & 40 & 7.8 & 48 \\
$101-200$ & 70 & 13.1 & 134 \\
$201-300$ & 100 & 18.4 & 266 \\
$301-400$ & 120 & 21.9 & 377 \\
$>400$ & 140 & 10.0 & 78 \\
150 yr cohort gap & & & \\
$50-150$ & 60 & 11.3 & 100 \\
$151-300$ & 100 & 18.4 & 266 \\
$301-450$ & 120 & 21.9 & 377 \\
$>450$ & 140 & 10.0 & 78 \\
\hline
\end{tabular}


$120 \mathrm{~cm}$ dbh a mean crown diameter of $10 \mathrm{~m}$ was used to reflect crown retrenchment in old trees based on observations at Windsor Great Park (Figure 2).

From the estimated mean crown cover per tree, the mean canopy cover per hectare was calculated for the different tree population scenarios, assuming circular crowns and no overlap between the crowns of adjacent trees.

\subsection{VARIATIONS IN COVER ACROSS A LANDSCAPE}

To illustrate how the tree density and canopy cover might vary across a landscape, the trees of all ages/pollarding stage were allocated randomly across a 100 ha landscape divided up into $10 \mathrm{~m}$ $10 \mathrm{~m}$ cells (i.e. 10,000 possible locations) for two of the 24 possible combinations of old tree density, age class, survival rate etc. The mean cover and the frequency of trees more than 300 years old for each 1 ha plot were then calculated.

\subsection{COMPARISON WITH TREE POPULATION STRUCTURE FOR REAL SITES}

The age structures of two protected sites were examined in relation to the model outputs:
Staverton Park, eastern England (Peterken 1969, Sibbett 1999) and Moccas Park, western England (Harding \& Wall 2000, unpublished data supplied by Saul Herbert). At both sites the main tree species are oaks with spreading crowns. Staverton Park is grazed by deer; below the canopy, there are dense stands of bracken Pteridium aquilinum (L.) Kuhn patches of bramble Rubus spp., honeysuckle Lonicera periclymenum L. and grassy glades Holcus mollis L. and Dactylis glomerata L. There are also small areas of acid grassland with some heathland elements (http:// www.sssi.naturalengland.org.uk/Special/sssi/ sssi_details.cfm?sssi_id=1001023). Moccas has both deer and sheep as grazers. The ground flora is dominated by bracken on the slopes, but parts of the grassland in the park have been agriculturally improved (http://www.sssi. naturalengland.org.uk/Special/sssi/sssi_details. cfm?sssi_id=1002723).

\section{RESULTS}

Estimates of the mean number of trees per hectare and the corresponding canopy covers are given for a range of assumptions (Tables 3 and 4).

Table 3: Number of replacement trees in different age classes to maintain 2 trees $>400 \mathrm{yr}$ per hectare.

Tabela 3: Število nadomestnih dreves v različnih starostnih razredih, ki vzdržuje gostoto 2 drevesi, starejši od 400 let na hektar.

\begin{tabular}{|c|c|c|c|c|c|c|}
\hline \multirow[t]{3}{*}{ Target no of $>400 \mathrm{yr}$ trees $/ \mathrm{ha}$} & Loss rates $\%$ trees per annum & \multicolumn{5}{|c|}{ Tree age classes: 100 yr cohort gap } \\
\hline & & \multicolumn{5}{|l|}{ Target } \\
\hline & & $>400$ & $400-301$ & $300-201$ & $200-101$ & $50-100$ \\
\hline 2 & $0.5 / 0.5$ & 2 & 4 & 8 & 16 & 32 \\
\hline Canopy cover - pollards $\left(\mathrm{m}^{2} / \mathrm{ha}\right)^{*}$ & & 45 & 90 & 179 & 358 & 717 \\
\hline Canopy cover - maidens $\left(\mathrm{m}^{2} / \mathrm{ha}\right)$ & & 157 & 1506 & 2127 & 2151 & 1532 \\
\hline 2 & $0.5 / 0.33$ & 2 & 3 & 4.5 & 9 & 18 \\
\hline Canopy cover - pollards $\left(\mathrm{m}^{2} / \mathrm{ha}\right)^{*}$ & & 45 & 67 & 101 & 202 & 403 \\
\hline Canopy cover - maidens $\left(\mathrm{m}^{2} / \mathrm{ha}\right)$ & & 157 & 1130 & 1196 & 1210 & 862 \\
\hline \multirow[t]{3}{*}{ Target no of $>400 \mathrm{yr}$ trees $/ \mathrm{ha}$} & $\begin{array}{l}\text { Loss rates } \% \text { trees per annum } \\
<300 \mathrm{yr} />300 \mathrm{ys}\end{array}$ & \multicolumn{5}{|c|}{ Tree age classes: 150 yr cohort gap } \\
\hline & & \multicolumn{5}{|l|}{ Target } \\
\hline & & $>450$ & $450-301$ & $300-151$ & $150-50$ & \\
\hline 2 & $0.5 / 0.5$ & 2 & 4 & 8 & 16 & \\
\hline Canopy cover - pollards $\left(\mathrm{m}^{2} / \mathrm{ha}\right)^{*}$ & & 45 & 90 & 179 & 358 & \\
\hline Canopy cover - maidens $\left(\mathrm{m}^{2} / \mathrm{ha}\right)$ & & 157 & 1561 & 2127 & 1604 & \\
\hline 2 & $0.5 / 0.33$ & 2 & 3 & 6 & 12 & \\
\hline Canopy cover - pollards $\left(\mathrm{m}^{2} / \mathrm{ha}\right)^{*}$ & & 45 & 67 & 134 & 269 & \\
\hline Canopy cover - maidens $\left(\mathrm{m}^{2} / \mathrm{ha}\right)$ & & 157 & 1130 & 1595 & 1203 & \\
\hline
\end{tabular}

* Based on a mean canopy cover per tree over the rotation of $22.4 \mathrm{~m}^{2}$ 
Table 4: Total numbers of trees per ha and total percentage canopy cover for targets of 1, 2 and 4 trees per hectare $>400$ yr old.

Tabela 4: Skupno število dreves na hektar in skupen odstotek pokrovnosti krošenj za ciljno gostoto 1, 2 in 4 drevesa starejša od 400 let na hektar.

\begin{tabular}{|c|c|c|c|c|c|c|}
\hline \multirow[t]{2}{*}{ Target no trees/ha $>400 \mathrm{yr}$} & \multicolumn{2}{|c|}{1} & \multicolumn{2}{|c|}{2} & \multicolumn{2}{|c|}{4} \\
\hline & & & & & & \\
\hline Loss rate of tree per annum, $300 \mathrm{yr} />300 \mathrm{yr}$ & $0.5 / 0.33$ & $0.5 / 0.5$ & $0.5 / 0.33$ & $0.5 / 0.5$ & $0.5 / 0.33$ & $0.5 / 0.5$ \\
\hline No of trees per ha (all ages) & 18.2 & 31 & 36.5 & 62 & 73 & 124 \\
\hline Canopy cover - pollards $\left(\mathrm{m}^{2} / \mathrm{ha}\right)$ all ages & 410 & 695 & 820 & 1390 & 1640 & 2780 \\
\hline Canopy cover - maidens $\left(\mathrm{m}^{2} / \mathrm{ha}\right)$ all ages & 2277 & 3736 & 4555 & 7473 & 9110 & 14946 \\
\hline 150 yr cohort gap & & & & & & \\
\hline No of trees per ha (all ages) & 11.5 & 15 & 23 & 30 & 46 & 60 \\
\hline Canopy cover - pollards $\left(\mathrm{m}^{2} / \mathrm{ha}\right)$ all ages & 257 & 336 & 515 & 672 & 1030 & 1344 \\
\hline Canopy cover - maidens $\left(\mathrm{m}^{2} / \mathrm{ha}\right)$ all ages & 2043 & 2697 & 4086 & 5395 & 8172 & 10790 \\
\hline
\end{tabular}

There is considerable difference in the canopy cover of working wood-pasture where the trees are regularly pollarded and where there are wide-crowned trees, either because they are opengrown maiden trees or former pollards that have been neglected (Table 3). Where the trees are regularly pollarded a high degree of landscape openness can be combined with a relatively high density of trees including the younger generations needed to replace the cohorts of old trees. However, the canopy cover may be more than five times higher in unpollarded (or out-grown pollard) tree populations.

In unpollarded stands the young-mature cohorts contribute the bulk of the canopy cover (Table 3) because the crown size of old trees tends to decline through canopy retrenchment. The overall canopy cover of sites where the population consists mainly of the oldest age classes, with the younger ones missing, is therefore likely to be markedly less than where the population is more balanced, even if the overall density of trees is the same.

The overall canopy cover rapidly increases as the desired density of old trees (here defined as the number over $>400 \mathrm{yr}$ old per hectare) increases (Table 4).

\subsection{VARIATIONS ACROSS A 100 HA SITE}

When the mean numbers of trees per hectare from any of the above combinations were distributed at random across 100 ha site there was a consequent variation in cover and frequency of trees per ha. This is illustrated in Table 5 for the two options shown in bold in Table 4. Locally high densities can occur through irregular distribution of such trees, but this is balanced by more areas where they are scarce/absent, and greater distances between old trees, if the overall density is kept the same (Table 5).

Table 5: Variation in cover and frequency of trees per ha, based on random distribution of establishment across a 100 ha site.

Tabela 5: Variacija pokrovnosti in frekvence dreves na hektar na podlagi naključne razporeditve na površini 100 ha.

\begin{tabular}{|c|c|c|c|c|c|}
\hline \multirow[b]{2}{*}{$\begin{array}{c}\text { Mean no/ha } \\
>400 \mathrm{yr}\end{array}$} & \multirow[b]{2}{*}{ Cohort gap } & \multirow[b]{2}{*}{$\begin{array}{c}\text { Loss rate } \\
<300 \mathrm{yr} />300 \mathrm{yr}\end{array}$} & \multicolumn{2}{|c|}{$\begin{array}{c}\text { Range cover cover } \\
\% / \text { ha }\end{array}$} & \multirow[t]{2}{*}{$\begin{array}{c}\text { Range in no of trees } \\
>300 \mathrm{yr} / \mathrm{ha}\end{array}$} \\
\hline & & & Pollards & Maidens & \\
\hline 1 & 150 & $0.5 / 0.33$ & $0.8-4.7$ & $6.5-39.5$ & $0-8$ \\
\hline 2 & 100 & $0.5 / 0.5$ & $11-17$ & $50-100$ & $1-14$ \\
\hline
\end{tabular}




\subsection{COMPARISON WITH DATA FOR TWO PROTECTED SITES}

The size class distribution for oaks at two important English protected sites (Figure 3) are shown in Table 6 along with the estimates of crown-cover based on the stem diameter relationships used earlier. At both sites most of the trees are lapsed pollards that have now developed wide spreading crowns.
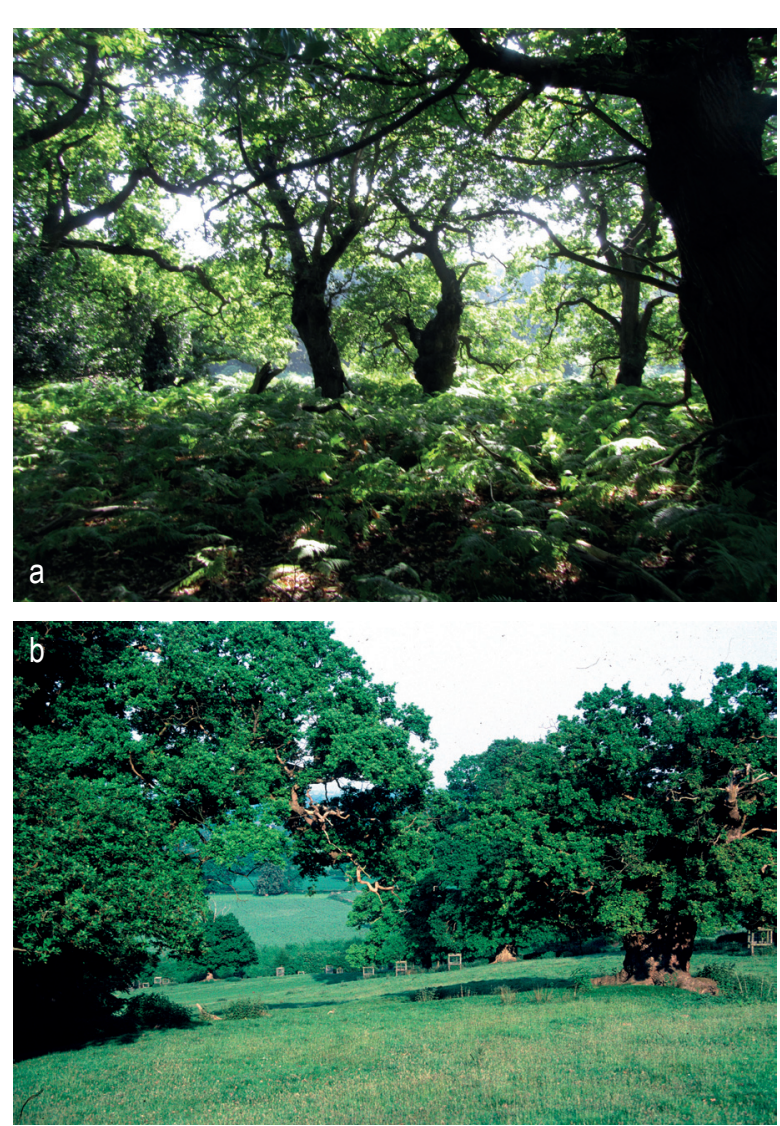

Figure 3: Typical views of (a) Staverton Park showing a high density of old trees and of (b) Moccas Park which is much more open. (Photographs by the author).

Slika 3: Značilen izgled (a) Staverton Park z visoko gostoto starih dreves in (b) Moccas Park, ki je bolj odprt. (Fotografije avtorja).

For Staverton Park (81 hectares) the numbers decline from one size class to the next by between about a half and third in the larger classes, but with progressively fewer trees in the smaller classes. For 10 trees per hectare in the $101-120 \mathrm{~cm} \mathrm{dbh}$ class it might be expected that there would be at least 20 in the $61-100 \mathrm{~cm}$ classes (rather than 16) and $30-40$ in the $21-40 \mathrm{~cm}$ classes rather than about 3 . The crown canopy cover estimates sug-
Table 6: Size class distribution and estimated canopy cover of oak for Staverton Park and Moccas Park.

Tabela 6: Velikostni razredi in predvidene pokrovnosti krošenj hrastov v parkih Staverton Park in Moccas Park.

\begin{tabular}{lccccc}
\hline $\begin{array}{l}\text { Stem dia- } \\
\text { meter class } \\
(\mathrm{cm})\end{array}$ & $\begin{array}{c}\text { Crown } \\
\text { diameter } \\
(\mathrm{m})\end{array}$ & \multicolumn{2}{c}{$\begin{array}{c}\text { Staverton } \\
\text { Park }(81 \mathrm{ha})\end{array}$} & \multicolumn{2}{c}{$\begin{array}{c}\text { Moccas } \\
\text { Park }(137 \mathrm{ha})\end{array}$} \\
& & $\begin{array}{c}\text { Tree } \\
\text { no/ha }\end{array}$ & $\begin{array}{c}\text { Crown cover } \\
\mathrm{m}^{2} / \mathrm{ha}\end{array}$ & $\begin{array}{c}\text { Tree } \\
\text { no/ha }\end{array}$ & $\begin{array}{c}\text { Crown } \\
\text { cover/ha }\end{array}$ \\
$21-40$ & 6.0 & 0.7 & 21 & 0.4 & 1 \\
$41-60$ & 9.6 & 1.9 & 138 & 0.8 & 58 \\
$61-80$ & 13.1 & 5.6 & 757 & 3.9 & 530 \\
$81-100$ & 16.6 & 9.7 & 2106 & 4.3 & 924 \\
$101-120$ & 20.1 & 9.7 & 3104 & 1.9 & 601 \\
$121-140$ & 10 & 5.9 & 464 & 0.7 & 53 \\
$141-160$ & 10 & 2.2 & 170 & 0.3 & 24 \\
$161-180$ & 10 & 0.8 & 67 & 0.2 & 15 \\
$180-200$ & 10 & 0.5 & 42 & 0.2 & 14 \\
$201-220$ & 10 & & & 0.3 & 24 \\
Overall \% & & & 68.7 & & 22.4 \\
cover & & & & & \\
\hline
\end{tabular}

gest nearly $70 \%$ cover presently by oak (there is also a very dense holly (Ilex aquifolium L.) understorey in half of the site). Adding in the missing trees would add about $20 \%$ canopy cover so the site would be virtually completely closed.

Moccas Park shows again the expected decline in the numbers of oak trees in the larger size class, but with a 'generation gap' of about 15 trees per hectare in the $21-60 \mathrm{~cm}$ dbh classes (given that there are about 8 per hectare in the $61-100$ $\mathrm{cm}$ class). The estimated canopy oak cover is only about $22 \%$ (not counting other tree species); adding in the missing trees would add another $7 \%$ canopy cover.

\section{DISGUSSION}

The model cannot be an exact reflection of reality, but the variables within it have been based as far as possible on realistic values either from the literature or from the author's field experience for oak-dominated wood-pastures in Britain. They are at the low end of the density of old trees per hectare found in important wood-pasture sites.

If the broad trends and differences identified are valid for the type of oak-dominated woodpastures common in Britain, certain conclusions follow. Conservation managers need to recognise that in protected sites where the density of old 
trees is already high (such as at Staverton Park, Table 6) there may not be sufficient space within the current boundaries to introduce the next cohort of trees to fill the 'generation gap' and still maintain current levels of openness. Even where there is the space (as at Moccas Park) the increase in the density of trees may change the character of the site.

Much higher densities of trees can be maintained where the trees are actively pollarded reducing the crown size; hence giving more opportunity for combining a sustainable population structure and high levels of openness. However, re-pollarding trees that have not been cut for decades, or even centuries, may lead to their death $(\operatorname{Read} 2000)$.

The extent of wood-pastures, many still actively maintained, in eastern and southern Europe has become more widely appreciated (Hartel \& Pleininger 2014). While some are dominated by oaks, as in western Europe, a wide range of other trees and priorities for management may be involved. The model might still be applicable to these but the parameters would need to be changed accordingly. If the requirement were only to maintain populations of oaks up to 200 years then fewer trees are need to produce a sustainable population structure, hence higher landscape openness is possible. If pollarding were on an annual or biannual cycle for leaf fodder (Kizos 2014) many more trees per hectare can be maintained with the same degree of landscape openness than if the branches must grow for longer to produce crops of acorns for pannage (Jørgensen 2013, Szabó 2013). A sustainable population of smallcrowned trees such as the pears (Pyrus spp.) associated with Balkan wood-pastures (Garbarino \& Bergmeier 2014) would allow a much higher level of openness than the same density of a largecrowned species such as oak or limes (Tilia spp.).

Wood-pastures as they exist today are a cultural landscape, shaped by centuries if not millennia of human influence. Analogies have been drawn between their structure and function and a possible structure for the pre-Neolithic landscape across north-west Europe (Vera 2000, but see also Hodder et al. 2009). In drawing such comparisons, the lack of younger trees and effect of active management as contributors to the high levels of openness seen in modern wood-pastures, need to be taken into account. A 'natural woodpasture' landscape where old, maiden oaks were present along with their future successors would not necessarily be a very open landscape unless the density of the old oaks was low, particularly if scrub and shorter-lived trees are to be fitted into the landscape amongst the oaks.

The generation gap is not necessarily important in the short term. The priority should be to maintain the existing old trees where they are at risk (Gibbons et al. 2008), for example by reducing the threats to them from deliberate felling or damage, competition from excessive adjacent regeneration or indirect threats such as pollution, changing. Various techniques have also been developed to try to speed up the development of rot holes etc in younger mature trees (Stokland et al. 2012). However the generation gap must eventually be filled if the species associated with old trees are to survive. Efforts should look at creating large-scale landscapes in which old trees can develop, centred on but not confined to the existing hot-spots for these important organisms.

\section{ACKNOWLEDGEMENTS}

This paper draws on published and unpublished work carried out while an employee of Nature Conservancy Council and its successors and discussions with numerous colleagues across a variety of organisations. My thanks for their ideas; any errors or misinterpretations are my own.

\section{REFERENCES}

Bieling, C. \& Konold, W. 2014: Common management of wood-pastures and sustainable regional development in the Black Forest (Germany). In: Hartel, T. \& Pleininger, T. (eds.): European wood-pastures in transition: a social-ecological approach. Earthscan / Routledge, Abingdon, UK, pp. 235-253.

Bergman, K. O. 2006: Living coastal woodlands: conservation of bidiversity in Swedish archipelagos. Swedish Forest Agency, Stockholm, $46 \mathrm{pp}$.

Bergmeier, E. \& Roellig, M. 2014: Diversity, threats and conservation of European woodpastures. In: Hartel, T. \& Pleininger, T. (eds.): European wood-pastures in transition: a social-ecological approach. Earthscan/Routledge, Abingdon, UK, pp. 19-38.

Butler, J. 2014: Mapping ancient and other trees of special interest: UK citizens' contribution 
to world tree heritage. In: Hartel, T. \& Pleininger, T. (eds.): European wood-pastures in transition: a social-ecological approach. Earthscan/Routledge, Abingdon, UK, pp. 203-216.

Dengler, J., Janišová, M., Török, P. \& Wellstein, C. 2014: Biodiversity of Palaearctic grasslands: a synthesis. Agriculture, Ecosystems \& Environment 182: 1-14.

Drobyshev, I., Niklasson, M., Linderson, H., Sonesson, K., Karlsson, M., Nilsson, S. G. \& Lanner, J. 2008: Lifespan and mortality of old oaks - combining empirical and modelling approaches to support their management in southern Sweden. Annals of Forest Science 65: 1-11.

English Nature 1998: UK Biodiversity Group: tranche 2 action plans. English Nature, Peterborough, UK. 69 pp. URL: jncc.defra.gov.uk/ PDF/UKBAP_Tranche2-Action PlansVol2-1998.pdf.

Falk, S. 2014: Wood-pastures as reservoirs for invertebrates. In: Hartel, T. \& Pleininger, T. (eds.): European wood-pastures in transition: a social-ecological approach. Earthscan/Routledge, Abingdon, UK, pp. 113-131.

Garbarino, M. \& Bergmeier, E. 2014: Plant and vegetation diversity in European wood-pastures. In: Hartel, T. \& Pleininger, T. (eds.): European wood-pastures in transition: a social-ecological approach. Earthscan/Routledge Abingdon, UK, pp. 113-131.

Gibbons, P., Lindenmayer, D. B., Fischer, J., Manning, A. D., Weinberg, A., Seddon, J., Ryan, P. \& Barrets, G. 2008: The future of scattered trees in agricultural landscapes. Conservation Biology 22: 1309-1319.

Harding, P. T. \& Alexander, K. N. A. 1993: The saproxylic invertebrates of historic parklands: progress and problems. In: Kirby, K. J. \& Drake, C. M. (eds.): Dead wood matters: the ecology and conservation of saproxylic invertebrates in Britain. English Nature, Peterborough, UK, pp. 58-73.

Harding, P. T. \& Rose, F. 1986: Pasture-woodlands in Lowland Britain. Institute of Terrestrial Ecology, Huntingdon, UK, 89 pp.

Harding, P. T. \& Wall, T. 2000: Moccas: an English deer park. English Nature, Peterborough, $\mathrm{UK}, 348 \mathrm{pp}$.

Hartel, T. \& Pleininger, T. (eds.) 2014: European wood-pastures in transition: a social-ecological approach. Earthscan/Routledge, Abingdon, UK, 303 pp.
Hartel, T., Hanspach, J., Abson, D. J., Máthé, O., Moga, C.I. \& Fischer, J. 2014: Bird communities in traditional wood-pastures with changing management in Eastern Europe. Basic and Applied Ecology 15: 385-395

Hedin, J., Ranius, T., Nilsson, S. G. \& Smith, H. G. 2008: Restricted dispersal in a flying beetle assessed by telemetry. Biodiversity and Conservation 17: 674-684.

Hodder, K. H., Buckland, P. C., Kirby, K. J. \& Bullock, J. M. 2009: Can the pre-Neolithic provide suitable models for re-wilding the landscape in Britain? British Wildlife, Supplement, 20: 4-15.

Jørgensen, D. 2013: Pigs and pollards: medieval insights for UK wood pasture restoration. Sustainability 5: 387-399.

Key, R. S. \& Ball, S. J. 1993: Positive management for saproxylic invertebrates. In: Kirby, K. J. \& Drake, C. M. (eds.): Dead wood matters: the ecology and conservation of saproxylic invertebrates in Britain. English Nature, Peterborough, UK, pp. 89-101.

Kirby, K. J. \& Perry, S. C. 2014: Institutional arrangements of wood-pasture management: past and present (UK). In: Hartel, T. \& Pleininger, T. (eds.): European wood-pastures in transition: a social-ecological approach. Earthscan/Routledge, Abingdon, UK, pp. 254-270.

Kirby, K. J., Thomas, R. C., Key, R. S., Mclean, I. F. G. \& Hodgetts, N. 1995: Pasture woodland and its conservation in Britain. Biological Journal of the Linnean Society 56: 135-153.

Kizos, T. 2014: Social-cultural values of oak wood-pastures and transhumance in Greece. In: Hartel, T. \& Pleininger, T. (eds.): European wood-pastures in transition: a social-ecological approach. Earthscan/Routledge, Abingdon, UK, pp. 171-184.

Newton, A. C. 2010: Biodversity in the New Forest. Pisces Publications, Oxford, UK, 237 pp.

Perry, S. C. 2013. A strategic view of the issues for wood-pasture and parkland conservation in England. In: Rotherham, I. D. (ed.): Trees, forested landscapes and grazing animals. Routledge, Abingdon, UK, pp. 356-375.

Peterken, G. F. 1969: Development of vegetation in Staverton Park, Suffolk. Field Studies 3: 1-39.

Peterken, G. F. \& Tubbs, C. 1965: Woodland regeneration in the New Forest, Hampshire, since 1650. Journal of Applied Ecology: 159-170. 
Rackham, O. 1989: The last forest. Dent, London, UK, 302 pp.

Ranius, T., Niklasson, M. \& Berg, N. 2009: Development of tree hollows in pedunculate oak (Quercus robur). Forest Ecology and Management 257: 303-310.

Read, H. J. 2000: Veteran trees: a guide to good management. English Nature, Peterborough, $\mathrm{UK}, 154 \mathrm{pp}$.

Rose, F. 1993: Ancient British woodlands and their epiphytes. British Wildlife 5: 83-93.

Rotherham, I. D. 2013: Trees, forested landscapes and grazing animals. Routledge, Abingdon, UK, 412 pp.

Savill, P. S. 1991: The silviculture of trees used in British forestry. CABI, Wallingford, UK, 143 pp.

Sibbett, N. 1999: Ancient tree survey of Staverton Parks and the The Thicks SSSI, Suffolk. English Nature Research Report 334: 1-31.

Stokland, J. N., Siitonen, J. \& Jonsson, B. G. 2012: Biodiversity in dead wood. Cambridge University Press, Cambridge, UK, 509 pp.
Szabó, P. 2013: Rethinking pannage: historical interactions between oak and swine. In: Rotherham, I.D. (ed): Trees, forested landscapes and grazing animals. Routledge, Abingdon, UK, pp. 62-70.

Tubbs, C. 1986: The New Forest: a natural history. Collins New Naturalist, London, UK, 300 pp.

Vera, F. W. M. 2000: Grazing ecology and forest history. CABI, Wallingford, UK, 506pp.

Watkins, C., Lavers, C. \& Howard, R. 2003: Veteran tree management and dendrochronology: Birklands and Bilhaugh cSAC, Nottinghamshire. English Nature Research Report 489: $1-34$.

Received: 31 January 2014

Accepted: 22 February 2015

Co-ordinating Editor: Jasmin Mantilla-Contreras 